\title{
The Relationship Between Mathematical Ability and Programming Ability of Computer Science Education Students
}

\author{
Delsika Pramata Sari, R. Ati Sukmawati, Iskandar Zulkarnain \\ Computer Education Study Program \\ Universitas Lambung Mangkurat \\ Banjarmasin, Indonesia \\ delsika.math@ulm.ac.id
}

\begin{abstract}
Mathematics is one of the sciences that can improve thinking skills and contribute to solving daily problems as well as the world of work. Some compulsory subjects in the Computer Science Education study program are in the field of mathematics. Also, one of the important things for students of Computer Science Education is programming ability. This fact underlined the purpose of this research. This study aims to examine whether there is a relationship between mathematical ability and programming ability of students of Computer Science Education. It employed a survey method with a correlational approach. The subject was 132 students of Computer Science Education. The technique sampling was a purposive random sampling. The quantitative data used to see the relationships were students' basic mathematics (BM) and basic programming (BP) data. The data was processed with IBM SPSS Statistics 25. Several previous studies revealed a relationship between these abilities descriptively. The difference with this research was quantitative testing the relationship between mathematical ability and programming ability. The finding of this study was that the average BM and BP scores of students have very small differences, which were 63.72 and 63.94 . It can be concluded that there was a strong relationship between mathematical ability and programming ability of students of Computer Science Education.
\end{abstract}

Keywords - mathematical ability; programming ability

\section{INTRODUCTION}

Curriculum serves as a guideline for the implementation of education as well as an illustration of what educational practices should be carried out and expected outcomes [1]. Based on the curriculum structure that applies in the Computer Science Education Study Program, there are seven courses in mathematics. These seven subjects are included in the compulsory field of expertise. This integration of mathematics courses indicates that the application of mathematics plays an important role in mastering computer science [2][3][4]. The Organization for Economic Co-operation and Development (OECD) states that mathematics is an important tool for young people because they face problems and challenges in their personal, work, social, and scientific aspects in their lives [5]. In other words, mathematics teaches students computational thinking and focuses on the application of solving real-world problems [6].
The development of 21 st-century information and communication technology is also based on the development of mathematics, including the branches of number theory, algebra, statistics and probability, and discrete mathematics [7]. The foundation of the branch of mathematics begins with the deepening of basic mathematical material. Therefore, basic mathematics courses are the foundation to support the development of students' mathematical ability.

Achieving thinking skills or dynamic mathematical ability such as reasoning, communication, connection, modeling, and mathematical problem solving requires a vehicle for communication in verbal and written forms [8] [9]. The vehicle for communication can be in the form of a single or multiple representations arranged in a mathematical language that expresses one's ideas to others or himself verbally or in writing, through symbols, graphs, tables, images, equations, concrete objects, or other forms. However, in the implementation of mathematics learning in higher education, the achievement of student representation ability is experiencing obstacles. Students do not understand the common thread among concepts, ideas, and material to be represented [8]. Mathematical representations are part of the mathematical ability.

The relationship with programming ability is that the mathematical representation is as a bridge that represents the ideas or languages used in making computer programs. A computer program is a software that contains a series of sequential instructions written to perform a series of tasks for a computer. Computer programs are made to facilitate human work. A language is needed in creating the program used to instruct the computer. This language is known as a programming language. A programming language is a set of syntax and semantic rules used to define computer programs. This language allows a programmer to determine exactly the data to be processed by a computer, how this data will be stored/forwarded, and what types of steps will be taken in various situations [10].

Programming ability is supported by an understanding of the programming language used. According to the level of proximity to computer machines, programming languages consist of several parts. First, a machine language: that is, 
languages that give commands to computers using binary language codes. Second, low level language that gives orders to computers using short codes. Thirds, a middle-level language which is a computer language that uses a mixture of instructions in human language words and symbolic codes. The last is high-level language as a series of instructions that use elements of human words so that they are easier to understand [10]. The programming languages used are for example ALGOL 68, Pascal, C, C ++, JavaScript, Java, etc. [10][11][12][13]. Characteristics of programming languages include: (1) the use of symbols, (2) the use of variables, constants, and operators, (3) the conditions, repetitions, and mathematical functions, and (4) the structured algorithms/steps. These characteristics are in line with mathematical characteristics. Also, the application of mathematical logic is closely related to making computer program algorithms [2] [3][4]. Then, based on the description above, the purpose of this study is to examine the relationship between mathematical ability and programming ability of students of Computer Science Education.

\section{METHOD}

\section{A. Research Subject}

Subjects of this study were 132 students of the Computer Science Education study program. The subjects of the study share common characters namely have completed basic math courses and basic programming. The subjects of this study were taken because the research subject had entered the formal operational stage. Where at this stage, an individual becomes more scientific and logical in the way they approach problems, can develop the ability to think more abstractly, can imagine hypothetical situations, and can determine possible outcomes without the need to observe [14]. The technique sampling used was a purposive random sampling.

\section{B. Data Collection}

The data in this study was collected using an achievement value data on basic mathematics courses and basic programming - achievement of basic mathematics courses to represent students' mathematical ability. The achievement of basic programming courses represents the programming ability of students. These two courses were chosen because they are fundamental subjects to support mathematical ability and programming ability.

\section{Data Analysis Technique}

The data was then analyzed by using quantitative data analysis. Quantitative data analysis is used to analyze the relationship between mathematical ability and programming ability of students of Computer Science Education. The form of quantitative data in this study included achievement value data in basic mathematics courses and basic programming. The data was processed with IBM SPSS Statistics with $\alpha=$ 5\%. Quantitative analysis of the relationship between mathematical ability and programming ability was done in the following stages:
- Creating a table of data of achievement of basic mathematics and basic programming

- Performing normality tests to determine the normality of data on basic mathematics achievement values and basic programming using the Kolmogorov-Smirnov statistical test. The data is normally distributed if the significance value is $>0.05$ ( $\mathrm{sig}$. 0.05). The hypothesis formulation on the normality test is $\mathrm{H}_{0}$ : Data is not normally distributed and $\mathrm{H}_{1}$ : Data is normally distributed.

- Conduct the Pearson Correlation test to determine the relationship between mathematical ability and the programming ability of students of Computer Science Education. If the value is a sig. $<0.05$, there is a significant relationship $\left(\mathrm{H}_{1}\right.$ is accepted $)$. The formulation of the hypothesis in the correlation test is: $\mathbf{H}_{\mathbf{0}}=$ There is no relationship between mathematical ability and the programming ability of students of Computer Science Education. $\mathbf{H}_{1}=$ There is a relationship between mathematical ability and the ability of programming students Computer Science Education.

\section{RESULTS AND DISCUSSION}

The results of this study are quantitative data obtained from the values achievement of basic mathematics courses (BM) and basic programming (BP). The data was processed from 132 students of the Computer Science Education program. The initial step of data analysis in this study was to analyze the achievement value data of basic mathematics courses and basic programming with descriptive statistics.

TABLE I. DATA OF BM AND BP ACHIEVEMENT

\begin{tabular}{|l|l|l|l|l|l|}
\hline & \multicolumn{1}{|c|}{ N } & Min & \multicolumn{1}{|c|}{ Max } & \multicolumn{1}{|c|}{ Mean } & \multicolumn{1}{c|}{ Std. Dev } \\
\hline BM & 137 & 0 & 91.70 & 63.72 & 18.49 \\
\hline BP & 137 & 0 & 94.00 & 63.94 & 14.99 \\
\hline
\end{tabular}

Based on Table I, the average value of Basic Mathematics and Basic Programming has a relatively small difference, namely 63.72 and 63.94 . The minimum value of the two courses is the same, which is 0 . The maximum value for the two courses is relatively small. The maximum value of Basic Mathematics 91.70 and the maximum value of Basic Programming is 94 . Therefore, it can be temporarily drawn that students' mathematical abilities are related to their programming ability.

This interim estimate is strengthened through inferential statistical analysis with IBM SPSS Statistics 25 with $\alpha=0.05$. Inferential statistical analysis begins with normality testing. The next testing steps are determined based on the normal distribution of the data obtained. 
TABLE II. NoRMAlity TEST RESUlts OF BM AND BP DATA

\begin{tabular}{|l|l|c|c|c|c|c|}
\hline & \multicolumn{2}{|c|}{ Kolmogorov-Smirnov } & \multicolumn{3}{c|}{ Shapiro-Wilk } \\
\cline { 2 - 7 } & Statistic & $\boldsymbol{d f}$ & Sig. & Statistic & df & Sig. \\
\hline BM & 0.106 & 137 & 0.001 & 0.936 & 137 & 0 \\
\hline BP & 0.168 & 137 & 0 & 0.857 & 137 & 0 \\
\hline
\end{tabular}

Criteria for testing hypotheses based on significance or sig., Ie if $\operatorname{sig} \geq \alpha$, then Ho is accepted. Seen in Table II shows sig. BM and BP data respectively $<0.05$ (KolmogorovSmirnov), then Ho is rejected. It means the data values of basic mathematics achievement and basic programming are not normally distributed.

Normal data on basic mathematics achievement values and basic programming of Computer Science Education students can be seen based on the results of the Q-Q Plot in Figures 1 and 2.

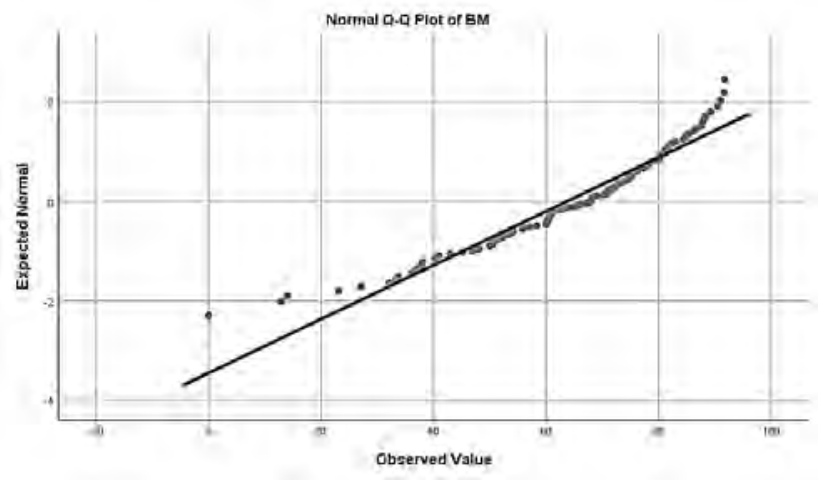

Fig. 1. Normality Test with QQ Plots for Basic Mathematics Data

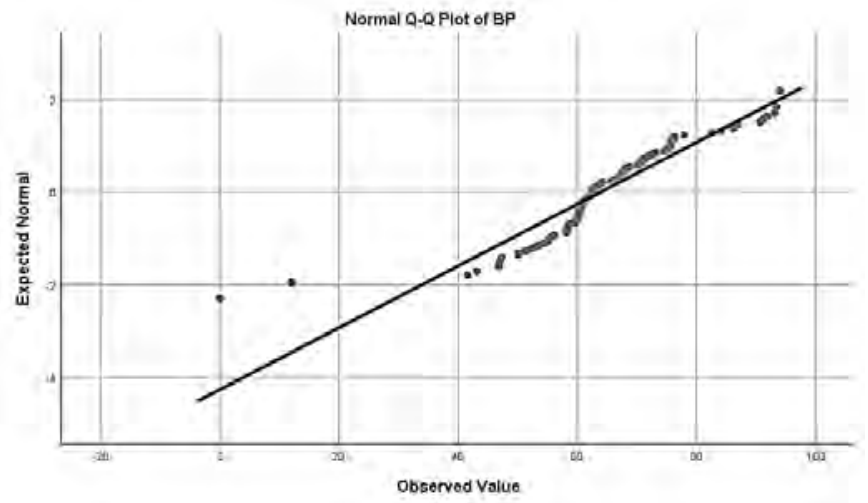

Fig. 2. Normality Test with QQ Plots for Basic Programming Data

Based on Figures 1 and 2, it can be seen that the distribution of $\mathrm{BM}$ and $\mathrm{BP}$ data has several data that are far from straight lines, meaning that the data in both classes are not normally distributed.

The next step is to do the Pearson Correlation test to find out the relationship between mathematical abilities and the programming ability of students of Computer Science Education. The Pearson Correlation data test results can be seen in Table III.
TABLE III. PEARSON CORRELATION TEST RESUlts OF BM AND BP DATA

\begin{tabular}{|c|c|c|c|}
\hline & & $\mathbf{B M}$ & BP \\
\hline \multirow[t]{3}{*}{ BM } & Pearson Correlation & 1 & 0.634 \\
\hline & Sig. (2-tailed) & & 0 \\
\hline & $N$ & 137 & 137 \\
\hline \multirow[t]{3}{*}{$\mathbf{B P}$} & Pearson Correlation & 0.634 & 1 \\
\hline & Sig. (2-tailed) & 0 & \\
\hline & $N$ & 137 & 137 \\
\hline
\end{tabular}

Table III shows that the Pearson Correlation (r) coefficient is 0.634 . It indicates that there is a strong relationship between mathematical abilities and programming ability of students of Computer Science Education. Furthermore, the direction of the relationship is positive because the value of $r$ is positive. So that, the higher the mathematical abilities of students, the higher their programming ability. Based on Table 3 , it is known that the significance value is $0(<0.05)$. This shows that the strength of the relationship between mathematical abilities and the programming ability of students in Computer Science Education is very significant.

The results of the analysis of descriptive and inferential statistical tests show that there is a relationship between mathematical ability and the programming ability of students of Computer Science Education. It is confirmed by previous studies [2][3][4]. This is because mathematics is an important tool for young people to face problems and challenges in their personal, work, social, and scientific aspects in their lives [5]. Especially teaching students computational thinking and focusing on the application of solving real-world problems [6]. Ref [15] further stated that mathematical contributions were very large in building and developing information technology and computers because mathematics is logic. In fact, the information technology and computers were made as a basis for programming; information technology and computer programming languages use binary numbers " 1 " and " 0 ", and their operations use mathematical algebraic operations; basic hardware and software development, basic development and determination of bits in a computer, basic network implementation and development [15].

\section{CONCLUSION}

It can be concluded that there is a relationship between mathematical abilities and programming ability in Computer Science Education students.

\section{ACKNOWLEDGMENT}

The authors thank Faculty of Teacher Training and Education, Universitas lambung Mangkurat for the support to accomplish this study.

\section{REFERENCES}

[1] N. Khodijah, F. S. Annur and N. Haitami, "Ketepatan penyusunan kurikulum prodi MPI Fakultas Ilmu Tarbiyah dan Keguruan UIN Raden Fatah Dikaitkan dengan KKNI, SN-DIKTI, dan Panduan Penyusunan Kurikulum Pendidikan Tinggi Tahun 2014," Journal of Islamic Education Management, vol. 2, no. 1, pp. 80- 100, 2016. 
[2] L. Cooper and M. W. Cooper, Introduction to dynamic programming: international series in modern applied mathematics and computer science, vol. 1, Texas: Pergamon Press, 2016.

[3] R. Bellman, A. O. Esogbue and N. Ichiro, Mathematical aspects of scheduling and applications: modern applied mathematics and computer science, vol. 4, Oxford: Pergamon Press, 2014.

[4] J. Vince, Mathematics for computer graphics, 5th ed., Breinton: Springer, 2017

[5] O. OECD, Draft PISA 2015 mathematics framework, Paris: OECD, 2013.

[6] E. J. Hom, "Livescience," What is STEM Education?," 2014. [Online]. Available: https://www.livescience.com/43296-what-is-stemeducation.html. [Accessed 111 2018].

[7] Z. Chairani, Metakognisi Siswa dalam Pemecahan Masalah Matematika, Yogyakarta: Deepublish, 2016.

[8] S. P. Dewanto, "Peranan kemampuan akademik awal, self-efficacy, dan variabel nonkognitif lain terhadap pencapaian kemampuan representasi multipel matematis mahasiswa melalui pembelajaran berbasis masalah," Educationist, vol. II, no. 2, pp. 123-133, 2008.

[9] OECD, PISA 2015 assessment and analytical framework: science, reading, mathematic and financial literacy, Paris: OECD Publishing, 2016a.
[10] J. Wahyudi, B. Berlian and R. Rosdiana, "Instruksi bahasa pemrograman ADT (Abstract Data Type) pada virus dan loop batch," Jurnal Media Infotama, vol. 9, no. 2, pp. 64-77, 2013.

[11] M. T. Pratama, "Evolusi bahasa pemrograman," Jurnal Computech \& Bisnis, vol. 8, no. 1, pp. 35-42, 2014.

[12] I. Yatini, "Aplikasi pengolahan citra berbasis web menggunakan javascript dan jquery," Jurnal Teknik, vol. 3, no. 3, pp. 1-8, 2014.

[13] A. Prihandono and E. Nurraharjo, "Implementasi java interface pada pembuatan aplikasi multimedia berbasis android," Jurnal Teknologi Informasi DINAMIK, vol. 20, no. 1, pp. 1-10, 2015.

[14] J. Chinappi and D. Cosmato, "Psychology and development of early adolescence: part two," 2012. [Online]. Available: https://www.brighthubeducation.com/teaching-methods-tips/3324psychology-and-development-of-early-adolescence-part-two/.[Accessed 2009 2018].

[15] Munir, "Direktori File UPI," 2012. [Online]. Available: http://file.upi.edu/Direktori/FPMIPA/PRODI._ILMU_KOMPUTER/196 603252001121-MUNIR/Artikel_TIK/E-Learning_Membangun_Sistem_ Pendidikan Berbasis Dunia Maya.pdf. [Accessed 2209 2018]. 